\title{
Diesel Exhaust Particulate
}

National Cancer Institute

\section{Source}

National Cancer Institute. Diesel Exhaust Particulate. NCI Thesaurus. Code C44374.

A complex mixture of combustion products of diesel fuel including carbon monoxide, carbon dioxide, sulfur oxides, nitrogen oxides, volatile hydrocarbons, aldehydes, alkenes, alkanes and nitroarenes, polycyclic aromatic hydrocarbons and other derivates. Lymphocyte-DNA adduct formation is associated with exposure to diesel exhaust particulates and may be associated with an increased risk of developing lung cancer. Diesel Exhaust Particulate is reasonably anticipated to be a human carcinogen. ( $\mathrm{NCl05)}$ 